\title{
Changes in the Sensitivity of Erwinia amylovora Populations to Streptomycin and Oxolinic Acid in Israel
}

\author{
S. Manulis, F. Kleitman, D. Shtienberg, and H. Shwartz, Department of Plant Pathology, ARO, the Volcani Cen- \\ ter, Bet Dagan 50250; D. Oppenheim and M. Zilberstaine, Ministry of Agriculture, Extension Service, Bet Dagan \\ 50250; and E. Shabi, Department of Plant Pathology, ARO, Bet Dagan 50250, Israel
}

\begin{abstract}
Manulis, S., Kleitman, F., Shtienberg, D., Shwartz, H., Oppenheim, D., Zilberstaine, M., and Shabi, E. 2003. Changes in the sensitivity of Erwinia amylovora populations to streptomycin and oxolinic acid in Israel. Plant Dis. 87:650-654.

A survey of streptomycin resistance in the fire blight pathogen, Erwinia amylovora, conducted in pear, apple, and quince orchards in Israel during 1998 to 2001 revealed a decrease in the frequency of locations with streptomycin-resistant strains, from 57\% in 1998 to $15 \%$ in 2001. In 2001, streptomycin-resistant strains were detected in only five locations in two restricted areas in western Galilee and the Golan Heights, compared with 16 locations found in 1998 throughout the northern part of the country. Since the use of streptomycin for fire blight control was terminated in 1997, this antibiotic has been replaced with oxolinic acid (Starner) in commercial orchards. Strains resistant to oxolinic acid were isolated from two pear orchards in the northern part of Israel in 1999. In a nationwide survey conducted during the spring and winter of 2000 and 2001, 51 and 47 pome fruit orchards, respectively, were sampled. Oxolinic acid-resistant strains were detected in several orchards located in two restricted areas in northern Galilee. Strains with resistance to both streptomycin and oxolinic acid were not found during 2000 to 2001. Results of this survey are used in managing fire blight with bactericides.
\end{abstract}

Fire blight, caused by the bacterium Erwinia amylovora, was first detected in Israel in $1985(15,21)$ and has been observed since then in pear, apple, quince, and loquat orchards throughout the country (16,20). Since 1986, streptomycin has been the only bactericide registered in Israel for fire blight management during bloom, and it has been widely used by pear growers, with up to 12 applications per season. Streptomycin-resistant E. amylovora strains were first detected in Israel in 1991 in an isolated pear orchard in the south. Following failure to control fire blight with streptomycin in 1995, the distribution of streptomycin-resistant strains of E. amylovora was surveyed in 109 pear, apple, loquat, and quince orchards (10). Resistant strains were recovered from infected flowers and branches collected at 18 locations in the central (Sharon) and northern (Galilee) growing regions of the country (10). Since 1997, streptomycin has been withdrawn from recommendation and replaced with oxolinic acid (Starner, S-0208), which has been exclusively recommended for fire blight management. Oxolinic acid is a quinolone antibiotic and is used for control

Corresponding author: S. Manulis

E-mail: shulam@volcani.agri.gov.il

Accepted for publication 7 January 2003.

Publication no. D-2003-0320-01R

(C) 2003 The American Phytopathological Society of bacterial diseases on rice and vegetables such as cabbage, potato, and onion (3); it is not widely used against fire blight. In 1997 to 2000, the efficacy of oxolinic acid against E. amylovora was evaluated in 43 orchard experiments in Israel (18). At a concentration of $300 \mu \mathrm{g} / \mathrm{ml}$, oxolinic acid was highly effective and significantly reduced disease severity in all experiments (18). Since 1998, oxolinic acid has been the only bactericide used against fire blight in pear and quince orchards in Israel; therefore, it is important to monitor any appearance of resistance to it. Similarly, it is important to find out how long streptomycinresistant strains of E. amylovora persist in orchards after termination of the use of this antibiotic. A preliminary report of this study was presented previously (9).

\section{MATERIALS AND METHODS}

Isolation of bacteria. Samples of infected tissue were collected from pear, apple, quince, and loquat orchards during the period from 1998 to 2001. E. amylovora was isolated from fire blight-infected flowers, shoots, or branches with visible cankers. The numbers of different locations and orchards from which infected tissues were collected are summarized in Table 1 . At least three samples from each orchard were tested. Small pieces of infected tissue were ground in $5 \mathrm{ml}$ of sterile water with a homogenizer (Pro200, Pro Scientific Inc., Monroe, LA), and 100- $\mu$ l samples of the homogenate were plated on CCT agar medium (6), on CCT $+100 \mu \mathrm{g}$ of strepto- mycin sulfate per $\mathrm{ml}$, and on $\mathrm{CCT}+5 \mu \mathrm{g}$ of oxolinic acid per ml (Starner, S-0208 formulated $20 \%$ WP, Sumitomo Chemicals Co., Osaka, Japan, or pure grade, Sigma Chemical Co., St. Louis, MO). The plates were incubated for 2 days at $28^{\circ} \mathrm{C}$. If bacteria grew on CCT $+5 \mu \mathrm{g}$ of oxolinic acid per $\mathrm{ml}$, the homogenate was also plated on $\mathrm{CCT}+50 \mu \mathrm{g}$ of oxolinic acid per $\mathrm{ml}$.

Identification of $\boldsymbol{E}$. amylovora. Characteristic colonies of $E$. amylovora (i.e., light purple, opalescent color with a faint purplish center) that grew on CCT and CCT + $100 \mu \mathrm{g}$ of streptomycin per ml were identified by polymerase chain reaction (PCR) with the primers and amplification conditions described by Bereswill et al. (1). Five characteristic colonies of E. amylovora obtained from each isolation were subjected to the PCR. Characteristic colonies that grew on CCT $+5 \mu \mathrm{g}$ of oxolinic acid per ml were tested by PCR and by pathogenicity tests on slices of immature pear fruits (13). Immature pear fruits (cv. Spadona) were collected during June and stored in sealed polyethylene bags at $1^{\circ} \mathrm{C}$. The fruits were surface sterilized with $70 \%$ ethanol and cut into transverse slices 0.5 $\mathrm{cm}$ thick. For each strain, three slices, each from a different fruit, were placed on a sterile moist filter paper, in a sterile plastic dish, and a well $(4 \mathrm{~mm}$ diameter $\times 4 \mathrm{~mm}$ deep) was cut into the cortical region of each slice using a sterile cork borer. To each well, $30 \mu \mathrm{l}$ of bacterial suspension, at a concentration of $1 \times 10^{8}$ cells per ml, was

Table 1. Summary of numbers of locations and orchards in Israel from which strains of $E r$ winia amylovora were obtained and examined for resistance to streptomycin and oxolinic acid

\begin{tabular}{ccc}
\hline Year & Locations $^{\mathrm{a}}$ & Orchards \\
\hline 1998 & $28,19^{\mathrm{b}}$ & $47,22^{\mathrm{b}}$ \\
1999 & 12 & 16 \\
2000 & 32 & 48 \\
2001 & 33 & 55 \\
\hline
\end{tabular}

a In 1998, 2000, and 2001, the regions from which samples were collected were Golan Heights, Galilee, Hula Valley, Sharon, southern coastal plain, and northern Negev. In 1999, no infected samples were found in the Hula Valley and northern Negev.

b In 1998, samples from 28 locations and 47 orchards were examined for streptomycin resistance and from 19 locations and 22 orchards for oxolinic acid resistance. After 1998, all samples were examined for resistance to both antibiotics. 
added. Bacterial inoculum was prepared by growing each strain overnight on a nutrient agar plate followed by dilution with 0.05 $\mathrm{M}$ phosphate buffer ( $\mathrm{pH}$ 6.5). The slices were maintained under humid conditions at $25^{\circ} \mathrm{C}$. Production of ooze in the well and blackening of the slice were observed after 4 to 5 days. Five colonies from each isolation were subjected to PCR and pathogenicity tests. Pathogenicity tests with the resistant strains were also conducted on immature pears that were dipped in a solution of oxolinic acid at $300 \mu \mathrm{g} / \mathrm{ml}$ (formulated 20\%).

Determination of the minimal inhibitory concentration (MIC) of oxolinic acid. Twenty different strains of E. amylovora isolated from pear, apple, loquat, or quince in different regions in Israel, before oxolinic acid was sprayed (8), were used for determining the MIC. The strains were grown overnight on $\mathrm{CCT}$ at $28^{\circ} \mathrm{C}$ and then were streaked on CCT containing oxolinic acid at $0.5,1,5,10$, or $20 \mu \mathrm{g} / \mathrm{ml}$. In addition, a suspension of $10^{8}$ cells per $\mathrm{ml}$ was prepared from each strain, and $50 \mu \mathrm{l}$ was spread on CCT plates containing the above-mentioned concentrations of oxolinic acid. Bacterial growth was examined after $48 \mathrm{~h}$ at $28^{\circ} \mathrm{C}$.

\section{RESULTS}

Distribution of streptomycin resistance. Surveys of resistance from 1998 to 2001 revealed a decrease in the number of locations with streptomycin-resistant $E$. amylovora strains. In 1998, streptomycinresistant strains were detected in 16 locations in three regions (Fig. 1), whereas in 2001 such strains were detected only in three locations in the Golan Heights and in two locations in Galilee. In the Sharon region, where resistance had been widespread in all orchards monitored from 1994 to 1997 (10) and in 1998, only sensitive strains were detected in 2001 (Fig. 1). When calculating the frequency of locations with resistance out of the total number of locations examined from 1994 to1998, an interesting picture emerged (Fig. 2). The frequency of locations with streptomycin-resistant strains increased steadily from 1994 to 1998 and reached $57 \%$ in 1998 . Following the withdrawal of streptomycin from use in 1997, the frequency of locations with resistant strains declined rapidly in the following years to $15 \%$ in 2001 (Fig. 2).

Since fire blight is a sporadic disease and did not develop each year in the same location, it was not possible to monitor streptomycin resistance in the same location every year. Table 2 summarizes the locations where fire blight developed during several years and resistance was monitored. In the northern Golan Heights, resistant populations were detected in two locations (Newe Ative and En Ziwan) from 1994 to1998, but in 2001 only sensitive strains were isolated. However, in the southern part of the Golan Heights, resistant strains were detected in three locations from 1998 to 2001. In Galilee, the resistant strains disappeared from all the locations except Adamit, and resistance did not develop in locations where sensitive strains had been detected before 1998 (Table 2). In the Sharon region, where all the strains
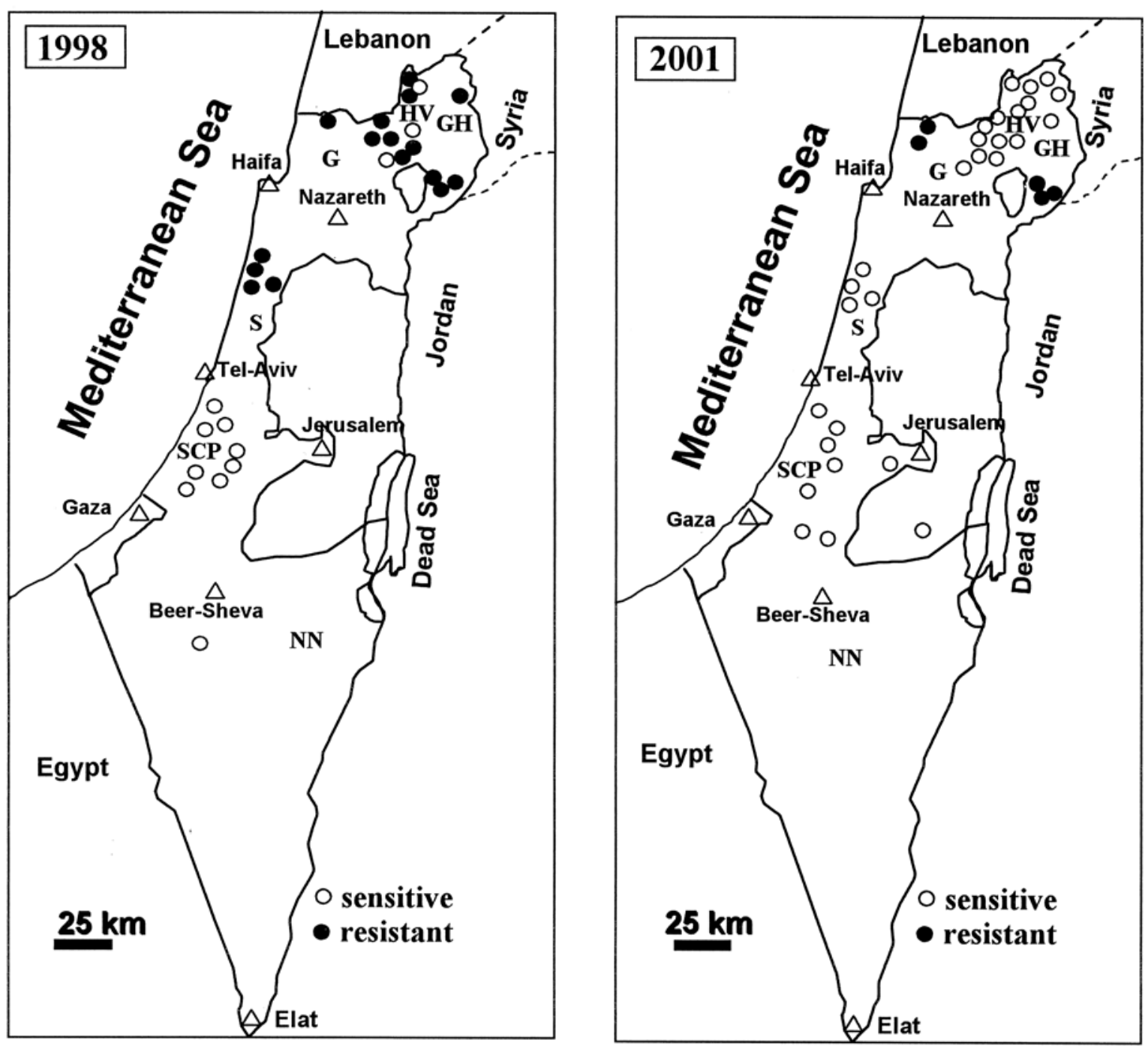

Fig. 1. Distribution of streptomycin-resistant and streptomycin-sensitive strains of Erwinia amylovora in various regions of Israel during 1998 and 2001. GH, Golan Heights; HV, Hula Valley; G, Galilee; S, Sharon; SCP, southern costal plain; NN, northern Negev. Triangles indicate locations of major cities. 
isolated during 1994 to 1998 were streptomycin-resistant, only streptomycin-sensitive strains were isolated in 2001. In the southern coastal plain, only streptomycin- sensitive strains were detected during the 8 years of the survey (Table 2).

Determination of MIC of oxolinic acid and isolation of resistant strains. Out of

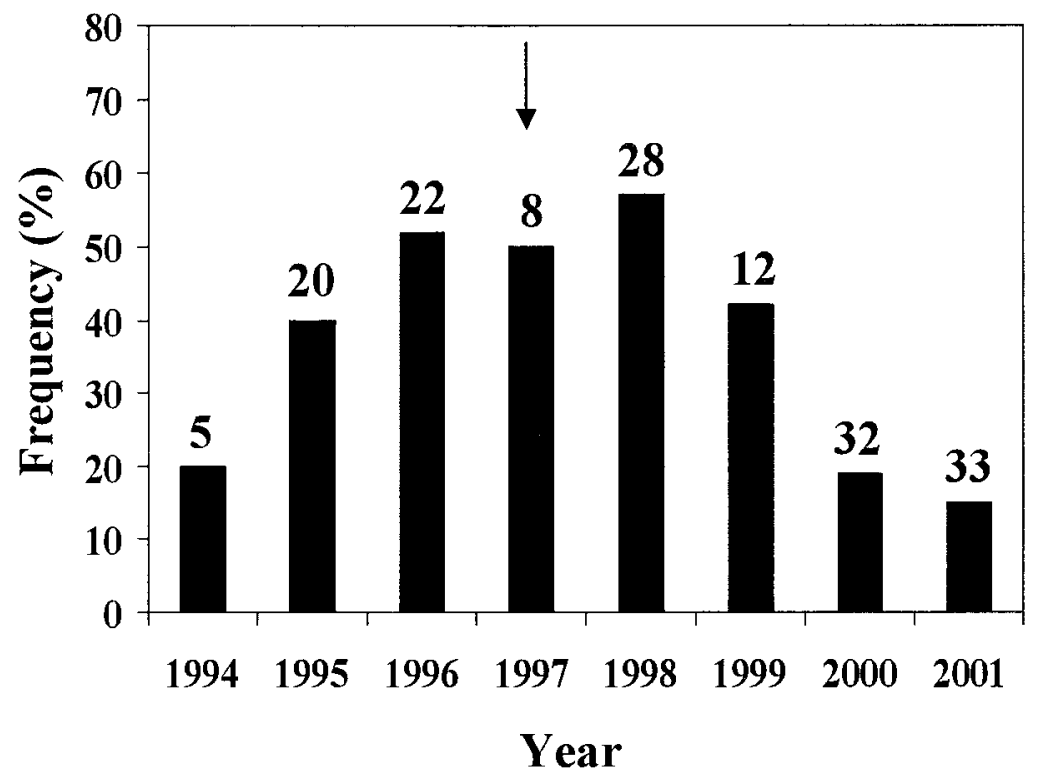

Fig. 2. Frequency of locations in Israel with streptomycin-resistant Erwinia amylovora during 1994 to 2001. Frequency is determined as the percentage of locations with streptomycin-resistant strains out of all locations with fire blight symptoms. Number adjacent to each column indicates the total locations examined each year. Arrow denotes the year when streptomycin was withdrawn from commercial use.

Table 2. Locations in Israel where resistance to streptomycin in Erwinia amylovora was monitored from 1998 to 2001

\begin{tabular}{|c|c|c|c|c|c|c|}
\hline Region & Location & $1994-1997^{a}$ & 1998 & 1999 & 2000 & 2001 \\
\hline \multirow{5}{*}{ Golan Heights } & Newe Ativ & $\mathrm{R}^{\mathrm{b}}$ & & & & $\mathrm{S}(2)$ \\
\hline & En Ziwan & $\mathrm{R}$ & $\mathrm{R}(1)$ & & & $\mathrm{S}(1)$ \\
\hline & Kanaf & & & $\mathrm{R}(3)$ & $\mathrm{R}(1)$ & $\mathrm{R}(1)^{\mathrm{c}}, \mathrm{S}(1)$ \\
\hline & Natur & & $\mathrm{R}(1)$ & $\mathrm{R}(1)$ & $\mathrm{R}(1)$ & $\mathrm{R}(1)$ \\
\hline & $\begin{array}{l}\text { Ramat } \\
\text { Magshimim }\end{array}$ & & $\mathrm{R}(1)$ & & & $\mathrm{R}(1)$ \\
\hline \multirow[t]{10}{*}{ Galilee } & Adamit & $\mathrm{R}$ & & & & $\mathrm{R}(2)$ \\
\hline & Baram & $\mathrm{R}$ & $\mathrm{R}(1)$ & & & \\
\hline & Yiftah & $\mathrm{R}$ & $\mathrm{R}(1)$ & & & $\mathrm{S}(5)$ \\
\hline & Kefar Yuval & $\mathrm{R}$ & $\mathrm{S}(1)$ & & & $\mathrm{S}(1)$ \\
\hline & Metulla & $\mathrm{S}$ & $\mathrm{S}(2), \mathrm{R}(1)$ & $\mathrm{S}(1)$ & $\mathrm{S}(2)$ & $\mathrm{S}(1)$ \\
\hline & Safsufa & $\mathrm{S}$ & $\mathrm{S}(1), \mathrm{R}(1)$ & $\mathrm{S}(1)$ & $\mathrm{S}(2)$ & $\mathrm{S}(1)$ \\
\hline & Rosh Pinna & $\mathrm{R}$ & $\mathrm{S}(3), \mathrm{R}(3)$ & $\mathrm{S}(1), \mathrm{R}(1)$ & $\mathrm{S}(3)$ & $\mathrm{S}(1)$ \\
\hline & Dishon & $\mathrm{S}$ & & & $\mathrm{S}(1)$ & \\
\hline & Farod & $\mathrm{S}$ & & & $\mathrm{S}(1)$ & $\mathrm{S}(2)$ \\
\hline & Shefer & & & $\mathrm{S}(1)$ & $\mathrm{S}(1)$ & \\
\hline \multirow[t]{4}{*}{ Sharon } & Binyamina & $\mathrm{R}$ & $\mathrm{R}(1)$ & $\mathrm{R}(1)$ & & $\mathrm{S}(2)$ \\
\hline & $\begin{array}{l}\text { Zikhron } \\
\text { Ya'aqov }\end{array}$ & $\mathrm{R}$ & $\mathrm{R}(1)$ & & & $\mathrm{S}(1)$ \\
\hline & Giv'at Ada & $\mathrm{R}$ & $\mathrm{R}(4)$ & & & $\mathrm{S}(1)$ \\
\hline & Shefiyya & $\mathrm{R}$ & $\mathrm{R}(1)$ & & $\mathrm{S}(1)$ & $S(1)$ \\
\hline \multirow{7}{*}{$\begin{array}{l}\text { Southern } \\
\text { Costal Plain }\end{array}$} & Gedera & $\mathrm{S}$ & $\mathrm{S}(1)$ & & & $\mathrm{S}(1)$ \\
\hline & Zerahya & $\mathrm{S}$ & $\mathrm{S}(4)$ & & $\mathrm{S}(1)$ & \\
\hline & $\begin{array}{l}\text { Kefar } \\
\text { Shemu'el }\end{array}$ & $\mathrm{S}$ & $\mathrm{S}(1)$ & & & \\
\hline & Gan Shelomo & $\mathrm{S}$ & $\mathrm{S}(1)$ & & & $\mathrm{S}(1)$ \\
\hline & Arogot & $\mathrm{S}$ & & & & $\mathrm{S}(1)$ \\
\hline & Nir Banim & & $\mathrm{S}(2)$ & & $\mathrm{S}(1)$ & \\
\hline & Devir & & & & $\mathrm{S}(1)$ & $\mathrm{S}(2)$ \\
\hline $\begin{array}{l}\text { Northern } \\
\text { Negev }\end{array}$ & Revivim & $S^{d}$ & $\mathrm{~S}(3)$ & & & \\
\hline
\end{tabular}

${ }^{a}$ Previously published results (10).

${ }^{\mathrm{b}} \mathrm{R}$, resistant to streptomycin $(100 \mu \mathrm{g} / \mathrm{ml})$; S, sensitive to streptomycin $(100 \mu \mathrm{g} / \mathrm{ml})$; empty spaces, no fire blight symptoms detected.

c Figures in parentheses represent number of orchards with resistant or sensitive strains.

${ }^{\mathrm{d}}$ Resistance was detected in 1991.

the 20 different strains of E. amylovora that were used for MIC determination, seven strains grew on $0.5 \mu \mathrm{g} / \mathrm{ml}$, but none grew on $1 \mu \mathrm{g} / \mathrm{ml}$ or above. Therefore, the MIC was estimated as $1 \mu \mathrm{g} / \mathrm{ml}$. The concentration of $5 \mu \mathrm{g} / \mathrm{ml}$ was used as a threshold to distinguish between susceptible and resistant isolates.

In 1998, 22 orchards in 19 different locations were examined for the presence of resistant strains, and no oxolinic acidresistant strains were detected. In 1999, samples were collected from 12 different locations and in two orchards in the Galilee and Golan Heights regions, and resistant strains were isolated on CCT plates containing oxolinic acid at $5 \mu \mathrm{g} / \mathrm{ml}$. The resistant strains were confirmed as E. amylovora by PCR reaction and by pathogenicity assay with immature pear fruits. The strains also were able to grow on oxolinic acid at $50 \mu \mathrm{g} / \mathrm{ml}$. In one orchard, the oxolinic acid-resistant strains were also resistant to streptomycin. In addition, immature pear fruits dipped in oxolinic acid at $300 \mu \mathrm{g} / \mathrm{ml}$ (the commercially used concentration) were inoculated with these strains. The oxolinic acid-resistant strains produced ooze and caused blackening of the pear slices, whereas the sensitive strain, used as a control, did not produce ooze or cause blackening (results not shown).

Distribution of oxolinic acid resistance. In 2000 and 2001, the incidence of fire blight was high; thus it was possible to collect samples from 32 and 33 locations, respectively. During 2000, oxolinic acidresistant strains were detected in 10 locations in the northern Hula Valley (Fig. 3), where there are pear, apple, and quince orchards. In all the other locations, only sensitive strains were found. In the winter of 2001, oxolinic acid-resistant strains were isolated from active cankers that developed in pear and quince in Amir (Fig. 3 ). In the spring of 2001, fire blight did not develop in all the locations, but resistant strains were detected in two locations in the Amir area, where resistance also had been detected in the previous year (Fig. 3). However, in an additional location (Yiftah), resistant strains were isolated from four different orchards (Fig. 3).

\section{DISCUSSION}

Streptomycin resistance in Israel developed gradually during the years when growers applied several sprays per season. Resistance was widespread in Galilee, Golan Heights, and Sharon regions, which are the main growing areas of pears and apples. Accordingly, streptomycin was removed from the list of pesticides approved for use in agriculture by the plant protection authorities in Israel. Since 1997, streptomycin has no longer been used commercially, and a gradual decline in the incidence of resistance was observed. The disappearance of resistance within 4 years of the withdrawal of streptomycin from use 
is surprising. In California, Schroth et al. (14) showed that the percentages of streptomycin-resistant bacteria in orchards declined from 1973 to 1977 , but resistant $E$. amylovora strains still could be isolated from infections even though streptomycin applications were terminated in 1971. In Washington, streptomycin-resistant strains of E. amylovora were isolated 5 years after termination of streptomycin use (7). In several apple orchards in Michigan, the frequency of streptomycin resistance declined from 1991 to 1992 when oxytetracycline rather than streptomycin was used (11). However, populations of streptomycin-resistant E. amylovora quickly rebounded in 1993 when streptomycin use was resumed (11). The disappearance of streptomycin-resistant strains can be attributed to the lower fitness of the resistant strains compared with the sensitive wild type. However, Loper et al. (7) found streptomycin-resistant isolates in pear and apple orchards that had never been sprayed with streptomycin, and accordingly, they suggested that resistant and sensitive strains had similar fitness capabilities in the absence of selection pressure. As far as we know, this conclusion was not supported by a study that compared the fitness capabilities of resistant and sensitive $E$. amylovora strains. Pseudomonas syringae pv. syringae strains harboring the plasmid conferring $\mathrm{Cu}$ and streptomycin resistance remained associated with the tree host even after bactericide selection pressure was withdrawn (19). Streptomycin resistance in
E. amylovora populations in Israel is not plasmid-mediated (10). It is possible that in locations where fire blight does not occur each season, the inoculum in the area is reduced and the next fire blight occurrence results from inoculum that is transported to the orchard from other locations by insects or other means. For example, in two locations north of the Golan Heights, Newe Ativ and En Ziwan (Table 2), where resistant strains were found from 1994 to 1998, fire blight was not observed during 1999 and 2000, but in 2001 a sensitive population was found. In contrast, in two locations in the south of the Golan Heights, Kanaf, and Natur (Table 2), fire blight occurred during 1998, 1999, and 2000 and thereby probably maintained the resistant population. In Ramat Magshimin, fire blight occurred in 1998 and again in 2001 with resistant strains. However, this location is close $(10 \mathrm{~km})$ to the other two locations where resistant populations were found. In Galilee, resistant strains disappeared from most of the locations, and after several years, a streptomycin-resistant population was found in only one place, Adamit. In the Sharon region, resistance was prevalent in all the pear, apple, and loquat orchards until 1998 (Table 2, Fig. 1). However, because of the severe outbreaks of fire blight during 1995 and 1996, many pear orchards were uprooted in this region, which reduced the source of resistant inoculum, and in 2000 to 2001 only sensitive strains were found. Years with mild fire blight epidemics, such as 1997 and 1999, could cause a reduction in the resistant inoculum.

Oxolinic acid is the only antibiotic used commercially against fire blight in Israel since 1998. Monitoring the resistance to oxolinic acid started in that year after the MIC had been determined. The MIC found for E. amylovora $(1 \mu \mathrm{g} / \mathrm{ml})$ is similar to that determined for other phytopathogenic bacteria such as E. carotovora subsp. atroseptica and E. carotovora subsp. carotovora (3). In contrast, phytopathogens belonging to the species Pseudomonas syringae, such as pvs. lachrymans, maculicola, or tabaci, have a higher MIC ( $25 \mu \mathrm{g} / \mathrm{ml})$, and for phytopathogens from the species Xanthomonas campestris, the MIC is $6.3 \mu \mathrm{g} / \mathrm{ml}$ (3).

In the spring of 2000 , resistant strains were found in quince orchards in kibbutz Amir, located in the Hula Valley; these orchards had been sprayed with oxolinic acid seven times during bloom. Resistant E. amylovora strains probably spread later from these orchards to pear and apple orchards located in the same area. In cankers that developed on pear trees in the winter of 2001, the oxolinic acid-resistant strains still persisted. In the spring of 2001, such strains were also detected in pear orchards in Upper Galilee (Yeftah). The clustering of orchards harboring oxolinic acidresistant E. amylovora in two separate areas indicates that resistance probably arose independently in each area.

This is the first report of the isolation of E. amylovora strains resistant to oxolinic acid. In Japan, resistant strains of Burk-
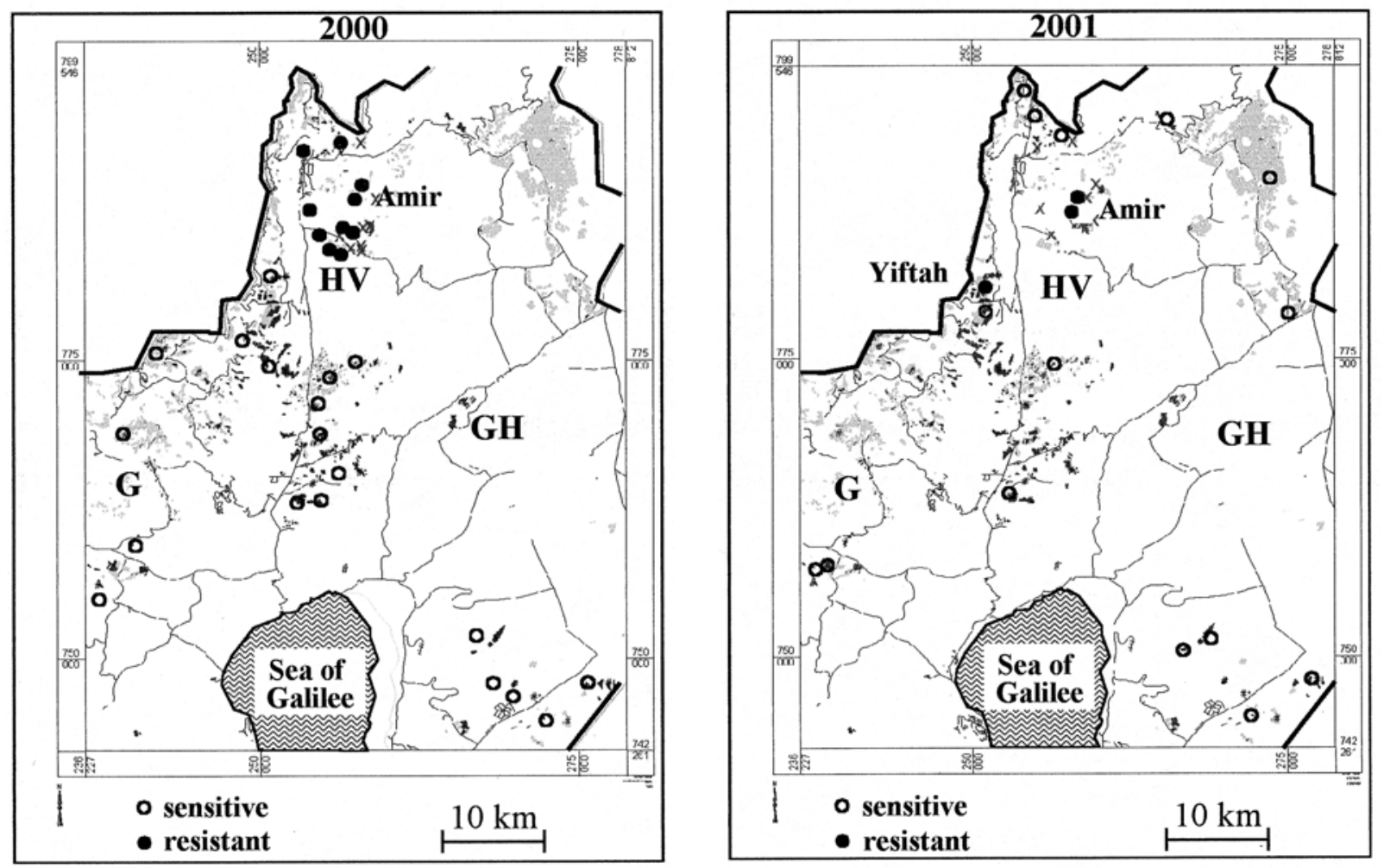

Fig. 3. Distribution of oxolinic acid-resistant and -sensitive strains of Erwinia amylovora in the northern part of Israel during 2000 and 2001 . GH, Golan Heights; HV, Hula Valley; G, Galilee. Data are based on spring and winter samples. Gray areas represent pear and apple orchards. 
holderia glumae and Acidovorax avenae, which are pathogenic to rice, were reported (4; T. Morikawa, Toyama, Japan, personal communication). The resistance of these pathogens was also demonstrated in field experiments (T. Morikawa, personal communication). The mode of action of quinolones against gram-negative bacteria is by inhibition of DNA gyrase (2). Resistance to quinolones can result either from a mutation in DNA gyrase or from a reduction in bacterial cell membrane permeability caused by a decrease in the outer membrane porin proteins $(5,12)$. Hikichi et al. (4) divided $B$. glumae into four groups, according to their resistance to oxolinic acid, which ranged from sensitive to highly resistant (higher than $100 \mu \mathrm{g} / \mathrm{ml}$ ); they suggested that the isolates in the various groups had different mechanisms of resistance. We detected $E$. amylovora strains resistant to $100 \mu \mathrm{g} / \mathrm{ml}$ but not to $1,000 \mu \mathrm{g} / \mathrm{ml}$. However, in immature pear fruits that were dipped in oxolinic acid at $300 \mu \mathrm{g} / \mathrm{ml}$ (the recommended concentration), the resistant bacteria induced disease symptoms, which suggests that in naturally infected flowers sprayed with this concentration, the strains are resistant. The mechanism of resistance in E. amylovora is not yet known and requires further investigation.

Two questions may be raised with respect to fire blight management. The first: What measures should be taken to lower the probability of resistance development in orchards where it has not yet developed? Disease management strategy aimed at reducing the likelihood of resistance development includes several components: (i) Use of suboptimal doses of the at-risk compound should be avoided. Although the efficacy of oxolinic acid at a rate of 200 $\mu \mathrm{g} / \mathrm{ml}$ did not differ significantly from that of $300 \mu \mathrm{g} / \mathrm{ml}$ (18), the recommended concentration is $300 \mu \mathrm{g} / \mathrm{ml}$. (ii) The at-risk compound should be alternated or applied as a mixture with compounds having different modes of action. Although a vast amount of effort was devoted in Israel to identifying additional bactericides that are effective against $E$. amylovora (18), none of the compounds tested was approved for use by the Israeli's plant protection authorities. Streptomycin received an emergency registration for use only in orchards where E. amylovora populations were found to be resistant to oxolinic acid. Thus, alternation or mixture of compounds is currently not an option for Israeli growers. (iii) Using the at-risk compound where large populations of the bacteria exist should be avoided. Growers are strictly advised not to apply oxolinic acid when infected blossom clusters are observed in the orchard; application is recommended only after all infected tissues have been removed and burned. (iv) The number of applications of the compound at risk should be reduced. Oxolinic acid is sprayed only when conditions are favorable for development of fire blight based on a local decision support system, i.e., Fire Blight Control Advisory (FBCA), developed by Shtienberg et al. (17). Use of FBCA enables the times of infection to be identified properly and enables fire blight to be adequately suppressed with one to three sprays per season. Implementation of these measures does not guarantee that strains of $E$. amylovora resistant to oxolinic acid would not develop, but it may lower the probability of their occurrence.

The second question that could be raised is how to manage E. amylovora in orchards where resistance to oxolinic acid has been detected and what measures should be taken to prevent the dispersal of resistant strains to neighboring orchards. A strain of E. amylovora that exhibited resistance to both streptomycin and oxolinic acid was detected in 1999 in a pear orchard in the Golan Heights (9). This orchard was uprooted due to the severe damage incited in trees by the pathogen. None of the strains isolated thereafter were resistant to both antibiotics. Accordingly, streptomycin has been used in orchards where populations of E. amylovora are resistant to oxolinic acid and also in orchards that are in close proximity to them. To reduce the amount of resistant inoculum, growers of orchards where resistance to oxolinic acid was detected were advised to conduct strict sanitation and to remove and burn all branches and limbs exhibiting fire blight symptoms. Trees showing fire blight symptoms as the result of invasion of the trunk by the bacterium were uprooted. The quince orchard in kibbutz Amir, where resistance to oxolinic acid was detected in spring 2000, was uprooted in winter 2002 because the disease was observed in trunks of approximately $30 \%$ of the trees, and it was no longer possible to eradicate the infected tissues from that orchard. In general, these recommendations were effective. For example, the spread of oxolinic acid-resistant strains from infected orchards in Amir and Yeftah (Fig. 3) to neighboring orchards was limited. In spring 2002, resistant strains were not observed in new orchards in these areas. Whether such measures are able to eradicate the oxolinic acid-resistant strains remains to be proven.

Isolation of E. amylovora strains from infected orchards and characterizing their response to oxolinic acid and streptomycin is currently an integral part of fire blight management in Israel. Samples of blossoms clusters, branches, and limbs exhibiting fire blight symptoms are readily delivered to the diagnostic laboratory at the Volcani Center, and the sensitivity of E. amylovora to both antibiotics is determined. Recommendations for disease management are based on the results of these tests.

\section{LITERATURE CITED}

1. Bereswill, S., Pahl, A., Bellemann, P., Zeller, W., and Geider, K. 1992. Sensitive and species-specific detection of Erwinia amylovora by polymerase chain reaction. Appl. Environ. Microbiol. 58:3522-3526.
2. Drlica, K., and Zhao, X. 1997. DNA gyrase, topoisomerase IV and the 4-quinolones. Microbiol. Mol. Biol. Rev. 61:377-392.

3. Hikichi, Y., Noda, C., and Shimizu, K. 1989. Oxolinic acid. Jpn. Pestic. Inform. 55:21-23.

4. Hikichi, Y., Tsujiguchi, K., Maeda, Y., and Okuno, T. 2001. Development of increased oxolinic acid-resistance in Burkholderia glumae. J. Gen. Plant Pathol. 67:58-62.

5. Hirai, K., Aoyama, H., Irikura, T., Oyobe, S. and Mitsuhashi, S. 1986. Differences in susceptibility to quinolones of outer membrane mutants of Salmonella typhimurium and Escherichia coli. Antimicrob. Agents Chemother. 29:535-538.

6. Ishimaru, C., and Klos, E. J. 1984. A new medium for detecting Erwinia amylovora and its use in epidemiological studies. Phytopathology 74:1342-1345.

7. Loper, J. E., Henkels, M. D., Roberts, R. G. Grove, G. G., Willet, M. J., and Smith, T. J. 1991. Evaluation of streptomycin, oxytetracycline, and copper resistance of Erwinia amylovora isolated from pear orchards in Washington State. Plant Dis. 75:287-290.

8. Manulis, S., Kleitman, F., Dror, O., David, I., and Zutra, D. 1998. Characterization of the Erwinia amylovora population in Israel. Phytoparasitica 26:39-46.

9. Manulis, S., Kleitman, F., Dror, O., and Shabi, E. 2000. Isolation of strains of Erwinia amylovora resistant to oxolinic acid. IOBC WPRS Bull. 23:89-92.

10. Manulis, S., Zutra, D., Kleitman, F., Dror, O., David, I., Zilberstaine, M., and Shabi, E. 1998. Distribution of streptomycin-resistant strains of Erwinia amylovora in Israel and occurrence of blossom blight in the autumn. Phytoparasitica 26:223-230.

11. McManus, P. S., and Jones, A. L. 1994. Epidemiology and genetic analysis of streptomycin-resistant Erwinia amylovora from Michigan and evaluation of oxytetracycline for control. Phytopathology 84:627-633.

12. Nakamura, S., Nakamura, M., Kojima, T., and Yoshida, H. 1989. gryA and gyrB mutations in quinolone-resistant strains of Escherichia coli. Antimicrob. Agents Chemother. 33:254-255.

13. Norelli, J. L., and Gilpatrick, J. D. 1982 Techniques for screening chemicals for fire blight control. Plant Dis. 66:1162-1165.

14. Schroth, M. N., Thompson, S. V., and Moller, W. J. 1979. Streptomycin resistance in Erwinia amylovora. Phytopathology 69:565-568.

15. Shabi, E., and Zutra, D. 1987. Outbreaks of fire blight in Israel in 1985 and 1986. Acta Hortic. 217:23-31.

16. Shabi, E., and Zutra, D. 1989. Five years of fire blight in Israel. (Abstr.) Acta Hortic. 273:41.

17. Shtienberg, D., Kritzman, G., Herzog, Z., Oppenheim, D., Zilberstaine, M., and Blatchinsky, D. 1999. Development and evaluation of a decision support system for management of fire blight in pears. Acta Hortic. 489:385-392.

18. Shtienberg, D., Zilberstaine, M., Oppenheim, D., Herzog, Z., Manulis, S., Shwartz, H., and Kritzman, G. 2001. Efficacy of oxolinic acid and other bactericides in suppression of $\mathrm{Er}$ winia amylovora in pear orchards in Israel. Phytoparasitica 29:143-154.

19. Sundin, G. W., and Bender, C. L. 1994. Relative fitness in vitro and in planta of Pseudomonas syringae strains containing copper and streptomycin resistance plasmids. Can. J. Microbiol. 40:279-285.

20. Zilberstaine, M., Herzog, Z., Manulis, S., and Zutra, D. 1996. Outbreak of fire blight threatening the loquat industry in Israel. Acta Hortic. 411:177-178.

21. Zutra, D., Shabi, E., and Lazarovits, G. 1986. Fire blight on pear, a new disease in Israel. Plant Dis. 70:1071-1073. 